\title{
Effect of Plant Density and Nitrogen Management on Uptake of Major Nutrients in Sweet Corn (Zea mays var saccharata)
}

\author{
A. Anjaneyulu Naik ${ }^{1 *}$, M. Srinivasa Reddy ${ }^{1}$, P.V. Ramesh Babu ${ }^{1}$ and P. Kavitha ${ }^{2}$ \\ ${ }^{1}$ Department of Agronomy, ${ }^{2}$ Department of Soil Science \& Agricultural Chemistry, \\ Agricultural College, Mahanandi-518502, Andhra Pradesh, India \\ *Corresponding author
}

\section{A B S T R A C T}

Keywords

Plant density,

Nitrogen

management,

Uptake of major

nutrients, Sweet

corn

Article Info

Accepted:

26 May 2020

Available Online:

10 June 2020
A field experiment was conducted during kharif, 2018 at Agricultural College Farm, Mahanandi to assess "Effect of plant density and nitrogen management on yield and quality of sweet corn (Zea mays var Saccharata)". Among the plant densities tried, plant density at $\left(\mathrm{D}_{1}\right) 60 \mathrm{~cm}$ $\mathrm{X} 15 \mathrm{~cm}$ recorded that highest uptake of $\mathrm{N}, \mathrm{P}_{2} \mathrm{O}_{5}$ and $\mathrm{K}_{2} \mathrm{O}$ by the crop at all the growth stages. Among the nitrogen levels tried, application of $\left(\mathrm{T}_{5}\right) 125$ $\%$ RDN + FYM @ $10 \mathrm{t} \mathrm{ha}^{-1}$ at 25, 50 DAS and at harvest recorded the highest uptake of $\mathrm{N}, \mathrm{P}_{2} \mathrm{O}_{5}$ and $\mathrm{K}_{2} \mathrm{O}$ which was however, found parity with ( $\left.\mathrm{T}_{4}\right) 100 \% \mathrm{RDN}+\mathrm{FYM} @ 10 \mathrm{t} \mathrm{ha}^{-1}$. Plant density and nitrogen management treatments exhibited their superiority at the highest levels of plant density and nitrogen management over the other levels under chemical sources in enhancing green cob yield. The lowest cob yield was associated with non-supply of fertilizers.

\section{Introduction}

Sweet corn (Zea mays var. saccharata) also known as sugar corn is a variety of maize with high sugar content. Maize is grown under diversified environment unmatched by any another crop as the expansion of maize to new areas and environment still continues. Maize is achieving popularity among the farmers in India due to its flexible characteristics of suitability and adaptability to various agro-climates. Maize is the most productive coarse cereal crop species in utilizing radiant energy and has the highest capacity to produce carbohydrates per day as compared to other cereals. The crop is less susceptible to environmental threats and cost of cultivation per $\mathrm{kg}$ of grain is less compared to other cereals, which lead to drawing the attention of the farmers of Andhra Pradesh and India. Majority of the maize cultivated in the country is flint corn. However in recent years sweet corn is also gaining importance due to consumer preference in table purpose 
maize. Maintenance of plant density is the most important factor to get higher cob yields. Plant density is one of the very important cultural practices which decide grain yield as well as other agronomic attributes of this crop (Songoai, 2001).In addition to optimum plant population, Nitrogen management also play crucial role in enhancement of crop productivity. Nitrogen plays major role in various physiological activities of maize. It extends the leaf area effectively, delaying senescence and essential for initiation of ear and kernel.

Since kharif sweet corn is achieving importance due to its productivity and stable market price, there is need to establish a relationship between nitrogen levels and plant density. The knowledge on response of highly productive sweet corn hybrids to other levels of nitrogen than the present level of recommendations is meager. By considering these points an experiment was proposed to research on "Effect of Plant density and Nitrogen management on uptake of major nutrients in Sweet corn (Zea mays var. saccharata)".

\section{Materials and Methods}

A field experiment entitled "Effect of plant density and nitrogen management on yield and quality of sweet corn (Zea mays var Saccharata)" was conducted at Agricultural College Farm, Mahanandi during kharif, 2018. The experiment was carried out in randomized block design with factorial concept and the each treatment was replicated thrice. The treatments consisted of combination of three plant densities $\left(\mathrm{D}_{1}: 60\right.$ $\mathrm{cm}$ X $15 \mathrm{~cm}, \mathrm{D}_{2}: 60 \mathrm{~cm} \mathrm{X} 20 \mathrm{~cm}$, and $\mathrm{D}_{3}: 60$ $\mathrm{cm} X 25 \mathrm{~cm})$ and five nitrogen management levels $\left(\mathrm{T}_{1}\right.$ : control, $\mathrm{T}_{2}: 100 \% \mathrm{RDN}, \mathrm{T}_{3}: 75 \%$ RDN + FYM@10 t ha ${ }^{-1}, \mathrm{~T}_{4}: 100 \% \mathrm{RDN}+$ FYM @ $10 \mathrm{t} \mathrm{ha}^{-1}$ and $\mathrm{T}_{5}: 125 \% \mathrm{RDN}+\mathrm{FYM}$ @ $10 \mathrm{t} \mathrm{ha}^{-1}$ ) in Factor - I and Factor - II respectively. The soil was sandy loam and it was slightly alkaline in reaction with a $\mathrm{pH}$ of 8.08; EC of $0.25 \mathrm{dSm}^{-1}$, low in organic carbon $(0.49 \%)$ and available nitrogen $\left(166 \mathrm{~kg} \mathrm{ha}^{-1}\right)$, medium in available phosphorus (46.6 $\mathrm{kg} \mathrm{ha}^{-1}$ ) and high in potassium (675.3 $\left.\mathrm{kg} \mathrm{ha}^{-1}\right)$. A popular sweet corn hybrid in this region, sugar-75, released by a private company $\mathrm{M} / \mathrm{s}$ Syngenta India Limited, Baner, Pune, Maharashtra, was used for the study. The fertilizers such as urea, single super phosphate and muriate of potash were supply of NPK and the entire quantity of phosphorous as basal and potassium and nitrogen were applied in three equal splits at 10,30 and 50 DAS and other agronomical operations were carried out as per recommendation.

At each stage five plants from the border rows were picked and kept separately for recording plot wise yields and expressed in $\mathrm{kg} \mathrm{ha}^{-1}$. At harvest, the stover form net plot was thoroughly sun dried and drymatter yield was expressed as $\mathrm{kg} \mathrm{ha}^{-1}$. After recording the yields from the net plots, the cobs were collected from five tagged plants. These cobs are made into small pieces, dried under shade for five days and then were oven dried at $60^{\circ} \mathrm{c}$ to a constant weight. After recording their weights, the stover and cob samples were ground in Willley mill and were analyzed for the concentration of major nutrients as per the procedures outlined by Tandon (1993). The uptakes of major nutrients were estimated by using the formula:

$$
\begin{aligned}
& \text { Uptake of } \mathrm{N}, \mathrm{P} \text { and } \mathrm{K}\left(\mathrm{kg} \mathrm{ha}^{-1}\right)= \\
& \text { Nutrient Drymatter } \\
& \text { concentration }(\%) \mathrm{X} \text { yield }\left(\mathrm{kg} \mathrm{ha}^{-1}\right) \\
& 100
\end{aligned}
$$

The data obtained from experiment were subjected to statistical analysis as per the procedures outlined by Panse and Sukhtame (1967). 


\section{Results and Discussion}

Nitrogen uptake $\left(\mathrm{kg} \mathrm{ha}^{-1}\right)$ was significantly superior at higher planting density $60 \mathrm{~cm} \mathrm{X}$ $15 \mathrm{~cm}\left(13.03,139.71\right.$ and $237.37 \mathrm{~N} \mathrm{~kg} \mathrm{ha}^{-1}$ at 25, 50 DAS and harvest, respectively) compared to that of lower plant densities at all the stages of crop growth, which might be due to production of significantly the maximum stover yield at higher planting density of 60 $\mathrm{cm} \mathrm{X} 15 \mathrm{~cm}$. Nitrogen uptake $\left(\mathrm{kg} \mathrm{ha}^{-1}\right)$ of sweet corn increased significantly with each increase in the level of nitrogen up to with 125\% RDN + FYM@10 $\mathrm{t} \mathrm{ha}^{-1}$ at all the stages of crop growth. The highest nitrogen uptake $\left(\mathrm{kg} \mathrm{ha}^{-1}\right)$ was recorded with the application of $125 \%$ RDN + FYM @ $10 \mathrm{tha}^{-1}$ $\left(11.05,143.092\right.$ and $271.05 \mathrm{~N} \mathrm{~kg} \mathrm{ha}^{-1}$ at 25 , 50 DAS and harvest, respectively). The increased uptake of nitrogen by the crop due to increasing rates of nitrogen might be due to increased green cob and stover yields. These results of increasing trend of uptake over the remaining levels with incremental addition of nitrogen were consistent with findings of Ummed Singh et al., (2012).

Significantly the highest phosphorous content at 25, 50 DAS and at harvest (in stover and cob) was recorded with the planting density of $60 \mathrm{~cm} \mathrm{X} 15 \mathrm{~cm}$ which was superior over 60 $\mathrm{cm} \quad X \quad 20 \mathrm{~cm}$ and $60 \mathrm{~cm} \quad X \quad 25 \mathrm{~cm}$. Significantly, the highest phosphorus uptake $\mathrm{kg} \mathrm{ha}^{-1}$ of sweet corn was recorded at $125 \%$ RDN + FYM@10 t ha ${ }^{-1}$ and the lowest phosphorus uptake was registered in control. This higher uptake of $\mathrm{P}$ might be due to synergistic effect of $\mathrm{N}$ and $\mathrm{P}$ leading to higher yield and uptake of phosphorus. These results are in line with the findings of Sahoo and Mahapatra (2007), Ananthi et al., (2010) (Table 1-3).

Table.1 Effect of plant density and nitrogen management on uptake of major nutrients $\left(\mathrm{kg} \mathrm{ha}^{-1}\right)$ at 25 DAS in sweet corn (Zea mays var saccharata)

\begin{tabular}{|c|c|c|c|c|}
\hline \multirow[t]{2}{*}{ Treatments } & \multirow{2}{*}{$\begin{array}{c}\text { Drymatter }\left(\mathrm{kg} \mathrm{ha}^{-1}\right) \\
\text { At } 25 \text { DAS }\end{array}$} & \multicolumn{3}{|c|}{ Uptake (kg ha $\left.{ }^{-1}\right)$} \\
\hline & & $\mathbf{N}$ & $\mathbf{P}$ & $\mathbf{K}$ \\
\hline \multicolumn{5}{|l|}{ Plant density levels (D) } \\
\hline$D_{1}: 60 \mathrm{~cm} \times 15 \mathrm{~cm}$ & 482.3 & 13.0 & 1.8 & 17.1 \\
\hline$D_{2}: 60 \mathrm{~cm} X 20 \mathrm{~cm}$ & 334.7 & 8.4 & 1.3 & 11.2 \\
\hline$D_{3}: 60 \mathrm{~cm} \times 25 \mathrm{~cm}$ & 296.5 & 7.9 & 1.2 & 10.4 \\
\hline SEm \pm & 11.5 & 0.1 & 0.1 & 0.2 \\
\hline $\mathrm{CD}(\mathrm{p}=\mathbf{0 . 0 5})$ & 33.3 & 0.1 & 0.1 & 0.8 \\
\hline \multicolumn{5}{|l|}{ Nitrogen levels $(\mathbf{T})$} \\
\hline$T_{1}$ : control & 280.8 & 8.5 & 0.9 & 10.3 \\
\hline$T_{2}: 100 \%$ RDN & 329.7 & 10.8 & 1.4 & 14.2 \\
\hline $\mathrm{T}_{3}: 75 \%$ RDN + FYM @ $10 \mathrm{tha}^{-1}$ & 351.1 & 9.1 & 1.5 & 12.4 \\
\hline $\mathrm{T}_{4}: 100 \% \mathrm{RDN}+\mathrm{FYM} @ 10 \mathrm{tha}^{-1}$ & 416.7 & 9.3 & 1.5 & 13.0 \\
\hline$T_{5}: 125 \%$ RDN + FYM @ $10 \mathrm{tha}^{-1}$ & 477.5 & 11.0 & 1.8 & 14.6 \\
\hline SEm \pm & 14.8 & 0.1 & 0.1 & 0.3 \\
\hline $\mathrm{CD}(\mathrm{p}=\mathbf{0 . 0 5})$ & 43.0 & 0.2 & 0.1 & 1.0 \\
\hline \multicolumn{5}{|l|}{ Interaction D X T } \\
\hline SEm \pm & 25.7 & 0.1 & 0.1 & 0.6 \\
\hline CD $(p=0.05)$ & NS & 0.4 & 0.3 & 1.8 \\
\hline
\end{tabular}


Table.2 Effect of plant density and nitrogen management on uptake of major nutrients $\left(\mathrm{kg} \mathrm{ha}^{-1}\right)$ at 50 DAS in sweet corn (Zea mays var saccharata)

\begin{tabular}{|c|c|c|c|c|}
\hline \multirow[t]{2}{*}{ Treatments } & \multirow{2}{*}{$\begin{array}{c}\text { Drymatter }\left(\mathrm{kg} \mathrm{ha}^{-1}\right) \\
\text { At } 50 \text { DAS }\end{array}$} & \multicolumn{3}{|c|}{ Uptake (kg ha $\left.{ }^{-1}\right)$} \\
\hline & & $\mathbf{N}$ & $\mathbf{P}$ & $\mathbf{K}$ \\
\hline \multicolumn{5}{|l|}{ Plant density levels (D) } \\
\hline$D_{1}: 60 \mathrm{~cm} \times 15 \mathrm{~cm}$ & 6650.3 & 139.7 & 22.2 & 159.4 \\
\hline$D_{2}: 60 \mathrm{~cm} X 20 \mathrm{~cm}$ & 5016.5 & 106.9 & 13.6 & 117.7 \\
\hline$D_{3}: 60 \mathrm{~cm} \times 25 \mathrm{~cm}$ & 4358.7 & 99.0 & 8.8 & 104.9 \\
\hline SEm \pm & 149.8 & 1.3 & 2.5 & 3.8 \\
\hline $\mathrm{CD}(\mathrm{p}=\mathbf{0 . 0 5})$ & 434.1 & 3.8 & 7.3 & 11.2 \\
\hline \multicolumn{5}{|l|}{ Nitrogen levels (T) } \\
\hline$T_{1}$ : control & 4217.9 & 66.5 & 7.1 & 87.6 \\
\hline $\mathrm{T}_{2}: 100 \% \mathrm{RDN}$ & 5548.7 & 111. & 10.7 & 134.1 \\
\hline$T_{3}: 75 \%$ RDN + FYM @ $10 \mathrm{tha}^{-1}$ & 5339.6 & 129.4 & 13.6 & 126.5 \\
\hline $\mathrm{T}_{4}: 100 \%$ RDN + FYM @ $10 \mathrm{t} \mathrm{ha}^{-1}$ & 5784.4 & 124.9 & 14.9 & 138.9 \\
\hline $\mathrm{T}_{5}: 125 \%$ RDN + FYM @ $10 \mathrm{t} \mathrm{ha}^{-1}$ & 5826.7 & 143.9 & 28.1 & 149.7 \\
\hline SEm \pm & 193.4 & 1.6 & 3.2 & 4.9 \\
\hline $\mathrm{CD}(\mathrm{p}=\mathbf{0 . 0 5})$ & 560.5 & 4.9 & 9.4 & 14.4 \\
\hline \multicolumn{5}{|l|}{ Interaction D X T } \\
\hline SEm \pm & 335.8 & 2.9 & 5.6 & 8.6 \\
\hline $\mathrm{CD}(\mathrm{p}=\mathbf{0 . 0 5})$ & NS & 8.0 & NS & 25.0 \\
\hline
\end{tabular}

Table.3 Effect of plant density and nitrogen management on uptake of major nutrients $\left(\mathrm{kg} \mathrm{ha}^{-1}\right)$ at harvest in sweet corn (Zea mays var saccharata)

\begin{tabular}{|c|c|c|c|c|c|c|c|c|}
\hline \multirow[t]{3}{*}{ Treatments } & \multirow{2}{*}{\multicolumn{2}{|c|}{$\begin{array}{c}\text { Yield }\left(\mathrm{kg} \mathrm{ha}^{-1}\right) \\
\text { at harvest }\end{array}$}} & \multicolumn{6}{|c|}{ Uptake (kg ha $\left.{ }^{-1}\right)$} \\
\hline & & & \multicolumn{2}{|c|}{$\mathbf{N}$} & \multicolumn{2}{|c|}{$\mathbf{P}$} & \multicolumn{2}{|c|}{$\mathbf{K}$} \\
\hline & Stover & Cob & Stover & Cob & Stover & Cob & Stover & Cob \\
\hline \multicolumn{9}{|l|}{ Plant density levels (D) } \\
\hline$D_{1}: 60 \mathrm{~cm} \times 15 \mathrm{~cm}$ & 5207 & 11042 & 70.8 & 166.5 & 7.4 & 27.4 & 94.5 & 106.8 \\
\hline$D_{2}: 60 \mathrm{~cm} \times 20 \mathrm{~cm}$ & 4255 & 9680 & 53.6 & 166.1 & 5.1 & 26.7 & 73.0 & 91.2 \\
\hline$D_{3}: 60 \mathrm{~cm} \times 25 \mathrm{~cm}$ & 3999 & 11286 & 46.8 & 158.4 & 4.5 & 25.3 & 61.4 & 102.5 \\
\hline SEm \pm & 96.1 & 333.4 & 0.5 & 1.6 & 0.6 & 1.8 & 1.3 & 1.3 \\
\hline $\mathrm{CD}(\mathrm{p}=\mathbf{0 . 0 5})$ & 279.9 & 966.3 & 1.5 & 4.8 & 1.7 & NS & 3.8 & 3.8 \\
\hline \multicolumn{9}{|l|}{ Nitrogen levels (T) } \\
\hline$T_{1}$ : control & 3455 & 7249 & 38.1 & 78.6 & 3.1 & 13.1 & 55.3 & 67.2 \\
\hline$T_{2}: 100 \%$ RDN & 4077 & 9908 & 57.5 & 164.2 & 4.1 & 25.9 & 81.6 & 107.6 \\
\hline $\mathrm{T}_{3}: 75 \% \mathrm{RDN}+\mathrm{FYM} @ 10 \mathrm{tha}^{-1}$ & 4475 & 10734 & 63.0 & 175.0 & 6.7 & 27.0 & 83.2 & 101.8 \\
\hline $\mathrm{T}_{4}: 100 \% \mathrm{RDN}+\mathrm{FYM} @ 10 \mathrm{t} \mathrm{ha}^{-1}$ & 4929 & 12083 & 60.8 & 195.6 & 6.4 & 30.3 & 76.9 & 109.8 \\
\hline $\mathrm{T}_{5}: 125 \% \mathrm{RDN}+\mathrm{FYM} @ 10 \mathrm{t} \mathrm{ha}^{-1}$ & 5499 & 13372 & 66.1 & 204.9 & 7.4 & 36.0 & 84.7 & 114.5 \\
\hline SEm \pm & 124.7 & 430.5 & 0.6 & 2.1 & 0.8 & 1.3 & 1.7 & 1.7 \\
\hline $\mathrm{CD}(\mathrm{p}=\mathbf{0 . 0 5})$ & 361.4 & 1247.5 & 1.9 & 6.2 & 2.3 & 4.0 & 4.9 & 5.0 \\
\hline \multicolumn{9}{|l|}{ Interaction (D X T) } \\
\hline SEm \pm & 216.04 & 7455.6 & 1.1 & 3.7 & 1.3 & 2.3 & 2.9 & 3.0 \\
\hline $\mathrm{CD}(\mathrm{p}=0.05)$ & NS & NS & 3.3 & 10.8 & NS & 6.9 & 8.6 & 8.7 \\
\hline
\end{tabular}


Significantly the highest potassium uptake in sweet corn was recorded with the plant density of $60 \mathrm{~cm} \mathrm{X} 15 \mathrm{~cm}$ at all the growth stages The increased potassium uptake at higher densities might be due to more number of plants exploiting the nutrients from larger volume of the rhizosphere. With the each increment of nitrogen level the potassium uptake also increases in sweet corn at all the growth stages upto 125\% RDN + FYM @ 10 $\mathrm{t} \mathrm{ha}^{-1}$ This might be due to favorable effect of nitrogen on the uptake of potassium as well as increased green cob and stover yield. Significantly the highest potassium uptake was at a planting density of $60 \mathrm{~cm} \mathrm{X} 15 \mathrm{~cm}$ and with the application of $125 \%$ RDN + FYM @ $10 \mathrm{t} \mathrm{ha}^{-1}$ at all the growth stages. Similar findings were reported by Ananthi et al., (2010) and Ummed Singh et al., (2012).

It is concluded, among all the combinations, significantly highest yield parameters amd major nutrient uptake sweet corn were obtained with application of $125 \%$ RDN + FYM @ $10 \mathrm{t} \mathrm{ha}^{-1}$ at a planting density of 60 cm X $15 \mathrm{~cm}\left(1,11,111\right.$ plants ha $\left.{ }^{-1}\right)$ but it was on par with 100\% RDN + FYM @ $10 \mathrm{t} \mathrm{ha}^{-1}$ at a planting density of $60 \mathrm{~cm} \mathrm{X} 15 \mathrm{~cm}$ $\left(1,11,111\right.$ plants $\left.\mathrm{ha}^{-1}\right)$. Hence the application of $100 \%$ RDN + FYM @ $10 \mathrm{t} \mathrm{ha}^{-1}$ at a planting density of $60 \mathrm{~cm} \mathrm{X} 15 \mathrm{~cm}(1,11,111$ plants $\mathrm{ha}^{-1}$ ) for sweet corn may be recommended. However the results will have to be confirmed by conducting extensive field trails in farmer's fields on long term basis.

\section{References}

Ananthi, T., Amanullah, M.M. and Subramanian, K.S. 2010. Influence of mycorrhiza and synthetic fertilizers on soil nutrient status and uptake in hybrid maize. Madras Agricultural Journal. 97 (10-12): 374-378.

Panse, V.G and Sukhatme, P.V. (Revised by Shukatme, P.V and Ambe V.N.). 1985. Statistical Methods for Agricultural Workers. ICAR, New Delhi. Pp:100-174.

Sahoo, S.C. and Mahapatra, P.K. 2007. Yield and economics of sweet corn (Zea mays L.) as affected by plant population and fertility levels. Indian Journal of Agronomy. 52 (3): 239-242.

Songai, L. 2001. Understanding plant density effects on maize growth and development: An important issue to maximize grain yield. Cienc. Rural, 31: 159-168.

Tandon, H.L.S. 1993. Methods of Analysis of Soils, plants, Waters and Fertilizers. Fertilizers Development and Consultations Organization 204-204A Bhanot Corner, 1-2 Pam Posh Enclave, New Delhi.

Ummed Singh, Saad, A.A., Ram, T., Lek Chand, Mir, S.A and Aga, F.A. 2012. Productivity, economics and nitrogen use efficiency of sweet corn (Zea mays Saccharata) as influenced by planting geometry and nitrogen fertilization. Indian Journal of Agronomy. 57(1):4348.

\section{How to cite this article:}

Anjaneyulu Naik, A., M. Srinivasa Reddy, P.V. Ramesh Babu and Kavitha, P. 2020. Effect of Plant Density and Nitrogen Management on Uptake of Major Nutrients in Sweet Corn (Zea mays var Saccharata). Int.J.Curr.Microbiol.App.Sci. 9(06): 3656-3660.

doi: https://doi.org/10.20546/ijcmas.2020.906.430 